\title{
In the context of Interior Architecture departments in Turkey; Design studio (project) education
}

\author{
Serpil Özker ${ }^{1}$, and Elif Süyük Makaklı \\ ${ }^{1}$ Işık University, Faculty of Fine Arts, Department of Interior Architecture, Istanbul, 34398, Turkey \\ ${ }^{2}$ Iş1k University, Faculty of Architecture and Design, Department of Architecture, Istanbul, 34980, \\ Turkey
}

\begin{abstract}
The courses of design studio are the most weighted elements in education as an essential part of interior architecture education. There are areas where thinking and design skills of the students are improved yet it is different from other courses. Increased number of students for each academic member in the project courses conducted through a mentor system has resulted in failure to sustain project-oriented education actively and reduced the productivity quality of education. Accordingly, the purpose of this study is to address the educational methods applied in various forms in the design studio courses of Interior Architecture departments in Turkey.
\end{abstract}

Keywords: Interior architecture; interior architecture education; design studio; course plan.

\section{Introduction}

Interior Architecture is one of the modern professions that continuously renew itself with the impact of socio-cultural and economic changes. Therefore, it is inevitable that the Interior Architecture education is being shaped under different approaches. The interior architecture education is particularly guided by design studio courses, and the weight of design studios in education is substantial. According to James Reswick, design, a creative act, is a concept involving creation of a new and practical thing that has never existed before, [8]. Design is a creative process and the most fundamental elements of design group professions; and the education is the development of individuals' behaviors through training and directions. The purpose of professional trainings such as Architecture, Interior Architecture, etc. is to convey the method and pattern of the design education to students. Design education is an education model that starts by proposing a problematic to the student and which is realized through the knowledge of contact and reference points of the

\footnotetext{
a Corresponding author: elif.suyuk@isikun.edu.tr
} 
problematic and formation of methods that enable us to understand the system of relations [2]. Design studio includes a combined use of other courses taken within the educational process to learn and develop the act of design. A project subject is defined every semester as part of design studio to be completed at the end of the term. At some Interior Architecture departments, it is (usually) presented before a jury, while other departments requires only project delivery. Design studios executed with a jury system ensures evaluation of the project by different academic members. The education is shaped through one-to-one interviews, revisions and critics by the project jury. Even though the design is a physical outcome, the abstract actuality of the process leading the actuator to that outcome. Thus, design mainly focuses on how to conduct the process rather than what should be the result [10]. In a sense, the courses of design studio are the most weighted elements in education as an essential part of interior architecture education. With a privileged position in education, the Design Studio varies in terms of weight, hours, teaching procedures, etc. for individual Interior Architecture departments. Increased number of students for every academic member in the project courses conducted through developing group activities or a mentor system has resulted in failure to sustain project-oriented education actively and reduced the productivity and quality of education. In addition, establishment of many Interior Architecture departments results in different educational approaches and methods. Accordingly, the study addresses Interior Architecture Education, design, and design process, Interior Architecture departments in Turkey, their curriculum, and educational methods of design studio. To this aim, the purpose of this study is to discuss educational methods applied in various forms in the design studios of Interior Architecture departments in Turkey.

\section{Design Studio Education and Methods at Interior Architecture Departments}

Interior Architecture is a field of occupation institutionalized in order to utilize scientific, technical data to be reflected in design, which offers functional, creative, technical, aesthetic solutions to ensure user comfort in a space, including efforts to establish style and identity for the space [5]. Emerging as a profession in the 19th century, the interior architecture [1] entered the process of institutionalization as a specialty field and as a profession not long after when a higher education level program started [2] to be offered for the first time by Parson's School of Design, the U.S. in 1896. [3]. It inevitable that the educational methods vary for Interior Architecture departments, the number of which increases rapidly today. Presence of many departments shapes the education system under different aspects including theory, art, technique and application. Studies are conducted by taking into consideration the program measures of certain institutions in order for a uniform education. Nevertheless, since departments serve their own interests, the curricula look the same but they are shaped through different methods. Accordingly, most of the Interior Architecture departments consider CIDA criteria when establishing their curriculum structure [9]. CIDA is an international NGO providing accreditation for Interior Architecture education programs in the US and in Canada, with efforts to create standards of Interior Architecture education. According to CIDA, Interior Architecture aims to improve the quality of interior spaces with the purpose of increasing life quality and efficiency and ensure security of people on a professional level supported by education and experiences. The differences among curricula of Interior Architecture departments across Turkey are mainly reflected on course contents. The purpose of courses included in the curriculum is to target the project and adapt the student to the project. It is a new experience in design and for students with combined use of various communication tools. Students adopt a verbal language before attending design education, however, they also need visual 
language. In other words, they are faced with the ability of sketching, diagramming, visual thinking and presentation [8]. Based on such insights, the relation between the student and executor must complement one another. For Julian Beiart, there are three ways of addressing the relations among executor, student and knowledge: Executor is the conductor between the student and knowledge; student may act independently from the executor but they also depend on the executor. Executor interferes only when the student needs an executor. Beiart believes in the first place in the validity of the first method and then defends the validity of other methods in the following years [8]. Design studies represent a social environments driving creativity beyond exchange of knowledge and experiences. The design studio environment facilitates generation of new design knowledge and ideas rather than acting as a physical space where the design knowledge is defined and communicated [11]. Design studio is a creative process involving interaction between the student and executor. It features cooperative work from the analysis stage to project presentation. Tuğlu and Özker [9] lists the general teaching methods and spaces at the design studios as follows:

- Problem solving method (Discussion Method - Critical Environment)

- Individual Working Method (Individual Working Environments)

- Methods of Expression (Seminar Environment)

- Case Study Method (Library Environment)

- Execution/Experience Method (Model Building)

- Computer Usage Environment

Executor in today's design studios benefit from a mixed system combining many methods instead of a single educational method. Especially the spatial pattern of the workshop plays a key role in effective implementation of methods [11]. Educational methods of design studios, which vary for individual Interior Architecture departments, are usually as follows: Besides design studies conducted by the executor throughout the term, designer talks, design-designer workshops, exchange of ideas, research, analysis, or seminar days for experts or company owners, etc. are other course teaching methods. In addition, projects prepared during the term may be delivered in three ways depending on the critics: One-to-one discussion, group criticism, jury criticism [8]. The executor takes a key role in the design studio course. They must encourage students to do research and to study and help them to improve their skills in design, presentation, and effective speech. Students must consider the design studio space as an office and work in a disciplined manner, while the project executor encourages the student to work in a workshop environment.

\section{Design Studio Education at Interior Architecture Departments}

There are substantial differences among Interior Architecture departments across Turkey. Beyond that, the main problem of our education system is that despite serious increase in the number of departments, which are opened one after another every day, the number of trained academicians is low. In Turkey there are currently 54 Interior Architecture departments, and a new one joins them every day with the recent, fast increase in number. While the courses at departments with high placement are divided in branches, the number of academic members falls short of increased number of students in project courses. Maximum number of project students for each academic member must be ten for a productive education by the end of the term. When the number of students starts to exceed twelve, it will not be possible to speak of quality education for departments offering less 
course hours. The time of project courses must be long enough for both executor and student, facilitating sufficient time and space. The period of education at Interior Architecture departments is four years (eight semesters), and the students are obliged to deliver five term projects and one graduation project during their education life. Some departments prioritize the concept of design in their curriculum while others give precedence to applied training. Therefore, the content of design studies are determined by the agreed curricula. And this is reflected on the course hours of design studios. For example, an Interior Architecture department of some university offers 12 hours of design studio courses, while another department offers 6 hours (Table 1). This is caused by transferring courses from departments with excess hours to design studio, while number and hour of other courses are reduced. On the other hand, in a department where there are less hours of design studio courses, the hours and numbers are higher for other courses. It is not possible to create a productive project environment due to less course hours in the design studio. Curricula serve as the mirror of departments and they are shaped aligned with the purposes of education. Interior Architecture education is focused on architectural elements within faculties of architecture, while it focuses on art within faculties of arts [1]. For example, the course contents of a department may be comprised of mainly design courses like volume design, furniture design, while another department offers courses based on mainly structure courses like knowledge of building or building materials. This shows how courses of different qualities in the curricula of Interior Architecture departments divert from one another [9]. Especially the design approaches, content and measurements in design studio differ greatly form department to department. Some departments develop detail-oriented solutions, while others act only in a design-oriented manner. The most important stage of design courses is drawing (sketch). The place of drawing in architecture, interior architecture and other visual arts is indisputably clear [6]. Drawing, as the first step of design, ensures integration of student's imagination with design through a process that continues from the start to the last phase of the project to be delivered. Different methods applied in the design studio is particularly related with course hours being longer or shorter. The more sufficient is the time spared for project, the more possible it is for students to focus on their project. The design education previously adopted the shortcut when teaching limited expression techniques, the education programs have had their differences in time with various theories and methods included in the design studio education. In this sense, the most common techniques in design studio education include vertical studio, virtual studio, metaphor, evolutionary design, 9 square $\mathrm{G}$ method, analysis-synthesis and interdisciplinary practices [13]. Such various studio practices aims to address artistic and cultural values, to discuss design and to improve design experience. Design studio must be students' top timeconsuming course in their education at the school. The design studio must also serve as an office environment where learning is communicated, shared and discussed. Workshops for design studio course must be used only for the purposes of this course; and the student must be able to work comfortably inside and outside course hours at the design workshop. The most important aspect of design studios making it different from other classes is that they reflect a different lifestyle [4]. In this sense, the requirements of project courses must be taken into consideration to design spaces accordingly. A design studio must provide opportunity for "personal experience" from the beginning and facilitate an environment where individuals can be free in their conceptual worlds [12]. Therefore, the design studio and space must be defined to establish working criteria in terms of educational method. 
Table 1. Interior architecture departments, number of students, design studio course hours in Turkey.

\begin{tabular}{|c|c|c|c|c|c|c|c|c|}
\hline \multicolumn{9}{|c|}{ Interior architecture departments admitting students based on central placement examination } \\
\hline & University & Faculty & Department & $\begin{array}{l}\text { Point } \\
\text { Type }\end{array}$ & Quota & Language & Course & Hour \\
\hline 1 & Akdeniz University & Faculty of Fine Arts & $\begin{array}{l}\text { Interior Architecture and } \\
\text { Environmental Design }\end{array}$ & TM-1 & 35 & Turkish & Design Studio & 6 \\
\hline 2 & Anadolu University & $\begin{array}{l}\text { Faculty of Architecture and } \\
\text { Design }\end{array}$ & $\begin{array}{l}\text { Interior Architecture and } \\
\text { Environmental Design }\end{array}$ & MF-4 & 45 & Turkish & $\begin{array}{c}\text { Interior } \\
\text { Architecture Project }\end{array}$ & 8 \\
\hline 3 & $\begin{array}{l}\text { Bahçeşehir } \\
\text { University }\end{array}$ & $\begin{array}{l}\text { Faculty of Architecture and } \\
\text { Design }\end{array}$ & $\begin{array}{l}\text { Interior Architecture and } \\
\text { Environmental Design }\end{array}$ & TM-1 & 66 & English & $\begin{array}{c}\text { Interior } \\
\text { Architecture Design }\end{array}$ & 8 \\
\hline 4 & $\begin{array}{l}\text { Çukurova } \\
\text { University }\end{array}$ & Faculty of Fine Arts & $\begin{array}{l}\text { Interior Architecture and } \\
\text { Environmental Design }\end{array}$ & $\mathrm{MF}-4$ & 30 & Turkish & $\begin{array}{c}\text { Interior } \\
\text { Architecture Project }\end{array}$ & 8 \\
\hline 5 & $\begin{array}{l}\text { Fatih Sultan } \\
\text { Mehmet Vakıf } \\
\text { University }\end{array}$ & $\begin{array}{l}\text { Faculty of Engineering and } \\
\text { Architecture }\end{array}$ & Interior Architecture & $\mathrm{MF}-4$ & 50 & Turkish & $\begin{array}{c}\text { Arci } \\
\text { Interior } \\
\text { Architecture Design }\end{array}$ & 8 \\
\hline 6 & Gedik University & $\begin{array}{l}\text { Faculty of Fine Arts and } \\
\text { Architecture }\end{array}$ & $\begin{array}{l}\text { Interior Architecture and } \\
\text { Environmental Design }\end{array}$ & TM-1 & 50 & Turkish & Design Studio & 8 \\
\hline 7 & Gediz University & $\begin{array}{l}\text { Faculty of Engineering and } \\
\text { Architecture }\end{array}$ & Interior Architecture & $\mathrm{MF}-4$ & 50 & English & $\begin{array}{c}\text { Design Studio/ } \\
\text { Interior } \\
\text { Architecture Design }\end{array}$ & 8 \\
\hline 8 & $\begin{array}{l}\text { Hacettepe } \\
\text { University }\end{array}$ & Faculty of Fine Arts & $\begin{array}{l}\text { Interior Architecture and } \\
\text { Environmental Design }\end{array}$ & TM-1 & 55 & Turkish & İndoor Design & 8 \\
\hline 9 & $\begin{array}{l}\text { Hasan Kalyoncu } \\
\text { University }\end{array}$ & $\begin{array}{l}\text { Faculty of Fine Arts and } \\
\text { Architecture }\end{array}$ & $\begin{array}{l}\text { Interior Architecture and } \\
\text { Environmental Design }\end{array}$ & TM-1 & 60 & Turkish & $\begin{array}{c}\text { Interior } \\
\text { Architecture Project }\end{array}$ & 8 \\
\hline 10 & Işık University & $\begin{array}{l}\text { Faculty of Architecture and } \\
\text { Design }\end{array}$ & Interior Architecture & $\mathrm{MF}-4$ & 60 & English & $\begin{array}{c}\text { Interior } \\
\text { Architecture Design } \\
\text { Studio }\end{array}$ & 8 \\
\hline 11 & $\begin{array}{l}\text { İhsan Doğramacı } \\
\text { Bilkent University }\end{array}$ & $\begin{array}{l}\text { Faculty of Fine Arts, Design } \\
\text { and Architecture }\end{array}$ & $\begin{array}{l}\text { Interior Architecture and } \\
\text { Environmental Design }\end{array}$ & TM-1 & 165 & English & $\begin{array}{l}\text { Interior Design } \\
\text { Studio }\end{array}$ & 6 \\
\hline 12 & $\begin{array}{l}\text { İstanbul Arel } \\
\text { University }\end{array}$ & $\begin{array}{l}\text { Faculty of Engineering and } \\
\text { Architecture }\end{array}$ & Interior Architecture & $\mathrm{MF}-4$ & 54 & Turkish & Could not access inf & mation \\
\hline 13 & $\begin{array}{l}\text { İstanbul Bilgi } \\
\text { University }\end{array}$ & Faculty of Architecture & Interior Architecture & MF-4 & 50 & English & $\begin{array}{l}\text { Interior } \\
\text { Architecture } \\
\text { Workshop }\end{array}$ & 11 \\
\hline 14 & $\begin{array}{l}\text { İstanbul } \\
\text { Kemerburgaz } \\
\text { University }\end{array}$ & $\begin{array}{l}\text { Faculty of Engineering and } \\
\text { Architecture }\end{array}$ & $\begin{array}{l}\text { Interior Architecture and } \\
\text { Environmental Design }\end{array}$ & TM-1 & 50 & English & $\begin{array}{l}\text { Architecture } \\
\text { Design/ } \\
\text { Interior } \\
\text { Architecture and } \\
\text { Environmental } \\
\text { Design }\end{array}$ & 8 \\
\hline 15 & $\begin{array}{l}\text { İstanbul Technical } \\
\text { University }\end{array}$ & Faculty of Architecture & Interior Architecture & $\mathrm{MF}-4$ & 29 & Turkish & $\begin{array}{c}\text { Architecture } \\
\text { Project/ } \\
\text { Interior } \\
\text { Architecture Project }\end{array}$ & 8 \\
\hline 16 & $\begin{array}{l}\text { İstanbul Ticaret } \\
\text { University }\end{array}$ & $\begin{array}{l}\text { Faculty of Engineering and } \\
\text { Design }\end{array}$ & $\begin{array}{l}\text { Interior Architecture and } \\
\text { Environmental Design }\end{array}$ & TM-1 & 60 & Turkish & $\begin{array}{c}\text { Interior } \\
\text { Architecture Studio }\end{array}$ & 8 \\
\hline 17 & $\begin{array}{l}\text { İzmir Economi } \\
\text { University }\end{array}$ & $\begin{array}{l}\text { Faculty of Fine Arts and } \\
\text { Design }\end{array}$ & $\begin{array}{l}\text { Interior Architecture and } \\
\text { Environmental Design }\end{array}$ & TM-1 & 70 & English & Design Studio & 8 \\
\hline 18 & $\begin{array}{l}\text { Kadir Has } \\
\text { University }\end{array}$ & Faculty of Art and Design & $\begin{array}{l}\text { Interior Architecture and } \\
\text { Environmental Design }\end{array}$ & TM-1 & 50 & Turkish & $\begin{array}{c}\text { Interior } \\
\text { Architecture Studio }\end{array}$ & 9 \\
\hline 19 & $\begin{array}{l}\text { Karadeniz } \\
\text { Technical } \\
\text { University }\end{array}$ & Faculty of Architecture & Interior Architecture & MF-4 & 60 & Turkish & $\begin{array}{c}\text { Interior } \\
\text { Architecture Project }\end{array}$ & 8 \\
\hline 20 & Kocaeli University & $\begin{array}{l}\text { Faculty of Architecture and } \\
\text { Design }\end{array}$ & Interior Architecture & $\mathrm{MF}-4$ & 60 & Turkish & Indoor Design & 8 \\
\hline 21 & $\begin{array}{l}\text { KTO Karatay } \\
\text { University }\end{array}$ & $\begin{array}{l}\text { Faculty of Fine Arts and } \\
\text { Design }\end{array}$ & $\begin{array}{l}\text { Interior Architecture and } \\
\text { Environmental Design }\end{array}$ & TM-1 & 40 & Turkish & $\begin{array}{c}\text { Interior } \\
\text { Architecture Project }\end{array}$ & 8 \\
\hline 22 & Selçuk University & Faculty of Fine Arts & $\begin{array}{l}\text { Interior Architecture and } \\
\text { Environmental Design }\end{array}$ & TM-1 & 30 & Turkish & $\begin{array}{c}\text { Interior } \\
\text { Architecture Project }\end{array}$ & 6 \\
\hline 23 & Selçuk University & Faculty of Fine Arts & $\begin{array}{l}\text { Interior Architecture and } \\
\text { Environmental Design } \\
\text { (İkinci Öğretim) }\end{array}$ & TM-1 & 30 & Turkish & $\begin{array}{c}\text { Interior } \\
\text { Architecture Project }\end{array}$ & 6 \\
\hline 24 & $\begin{array}{l}\text { TOBB University } \\
\text { of Economics and } \\
\text { Technology }\end{array}$ & $\begin{array}{l}\text { Faculty of Fine Arts, Design } \\
\text { and Architecture }\end{array}$ & $\begin{array}{l}\text { Interior Architecture and } \\
\text { Environmental Design }\end{array}$ & TM-1 & 50 & Turkish & $\begin{array}{l}\text { Space Design } \\
\text { Studio }\end{array}$ & 8 \\
\hline 25 & Yaşar University & Faculty of Architecture & $\begin{array}{l}\text { Interior Architecture and } \\
\text { Environmental Design }\end{array}$ & TM-1 & 55 & English & $\begin{array}{c}\text { İntegral Interior } \\
\text { Architecture Studio }\end{array}$ & 8 \\
\hline
\end{tabular}


Table 1 continued. Interior architecture departments, number of students, design studio course hours in Turkey.

\begin{tabular}{|c|c|c|c|c|c|c|c|c|}
\hline & & Interior architecture depart & ents admitting stude & sed on $\mathrm{s}$ & ial talen & xamination & & \\
\hline & University & Faculty & Department & $\begin{array}{l}\text { Point } \\
\text { Type }\end{array}$ & Quota & Language & Course & Hour \\
\hline 1 & Atılım University & $\begin{array}{l}\text { Faculty of Fine Arts, Design } \\
\text { and Architecture }\end{array}$ & $\begin{array}{l}\text { Interior Architecture } \\
\text { and Environmental } \\
\text { Design }\end{array}$ & $\begin{array}{l}\text { Special } \\
\text { Ability }\end{array}$ & 40 & Turkish & Indoor Design & 10 \\
\hline 2 & Avrasya University & $\begin{array}{l}\text { Faculty of Engineering and } \\
\text { Architecture }\end{array}$ & $\begin{array}{l}\text { Interior Architecture } \\
\text { and Environmental } \\
\text { Design }\end{array}$ & $\begin{array}{l}\text { Special } \\
\text { Ability }\end{array}$ & 70 & Turkish & $\begin{array}{c}\text { Interior } \\
\text { Architecture Project }\end{array}$ & 8 \\
\hline 3 & Başkent University & $\begin{array}{l}\text { Faculty of Fine Arts, Design } \\
\text { and Architecture }\end{array}$ & $\begin{array}{l}\text { Interior Architecture } \\
\text { and Environmental } \\
\text { Design }\end{array}$ & $\begin{array}{l}\text { Special } \\
\text { Ability }\end{array}$ & 50 & Turkish & Design Studio & 8 \\
\hline 4 & Beykent University & $\begin{array}{l}\text { Faculty of Engineering and } \\
\text { Architecture }\end{array}$ & Interior Architecture & $\begin{array}{l}\text { Special } \\
\text { Ability }\end{array}$ & 121 & Turkish & Design Studio & 6 \\
\hline 5 & $\begin{array}{l}\text { Canik Başarı } \\
\text { University }\end{array}$ & $\begin{array}{l}\text { Faculty of Architecture and } \\
\text { Engineering }\end{array}$ & Interior Architecture & $\begin{array}{l}\text { Special } \\
\text { Ability }\end{array}$ & 60 & Turkish & Project & 8 \\
\hline 6 & $\begin{array}{l}\text { Çankaya } \\
\text { University }\end{array}$ & Faculty of Architecture & Interior Architecture & $\begin{array}{l}\text { Special } \\
\text { Ability }\end{array}$ & 70 & Turkish & Design Studio & 10 \\
\hline 7 & Doğuş University & Faculty of Art and Design & Interior Architecture & $\begin{array}{l}\text { Special } \\
\text { Ability }\end{array}$ & 35 & Turkish & Project & 6 \\
\hline 8 & Haliç University & Faculty of Architecture & Interior Architecture & $\begin{array}{l}\text { Special } \\
\text { Ability }\end{array}$ & 87 & Turkish & Project & 8 \\
\hline 9 & Işık University & Faculty of Fine Arts & Interior Architecture & $\begin{array}{l}\text { Special } \\
\text { Ability }\end{array}$ & 80 & Turkish & Project & 6 \\
\hline 10 & $\begin{array}{l}\text { İstanbul Aydın } \\
\text { University }\end{array}$ & $\begin{array}{l}\text { Faculty of Architecture and } \\
\text { Design }\end{array}$ & Interior Architecture & $\begin{array}{l}\text { Special } \\
\text { Ability }\end{array}$ & 80 & Turkish & $\begin{array}{c}\text { Interior } \\
\text { Architecture Design }\end{array}$ & 8 \\
\hline 11 & $\begin{array}{l}\text { İstanbul Gelişim } \\
\text { University }\end{array}$ & Faculty of Fine Arts & $\begin{array}{l}\text { Interior Architecture } \\
\text { and Environmental } \\
\text { Design }\end{array}$ & $\begin{array}{l}\text { Special } \\
\text { Ability }\end{array}$ & 70 & Turkish & Project & 8 \\
\hline 12 & $\begin{array}{l}\text { İstanbul Kültür } \\
\text { University }\end{array}$ & Faculty of Art and Design & $\begin{array}{l}\text { Interior Architecture } \\
\text { and Environmental } \\
\text { Design }\end{array}$ & $\begin{array}{l}\text { Special } \\
\text { Ability }\end{array}$ & 55 & Turkish & $\begin{array}{c}\text { Interior } \\
\text { Architecture Project }\end{array}$ & 8 \\
\hline 13 & İzmir University & Faculty of Architecture & $\begin{array}{l}\text { Interior Architecture } \\
\text { and Environmental } \\
\text { Design }\end{array}$ & $\begin{array}{l}\text { Special } \\
\text { Ability }\end{array}$ & 70 & Turkish & $\begin{array}{c}\text { Interior } \\
\text { Architecture }\end{array}$ & 8 \\
\hline 14 & Maltepe University & Faculty of Architecture & Interior Architecture & $\begin{array}{l}\text { Special } \\
\text { Ability }\end{array}$ & 88 & Turkish & Design Studio & 12 \\
\hline 15 & Maltepe University & Faculty of Architecture & Interior Architecture & $\begin{array}{l}\text { Special } \\
\text { Ability }\end{array}$ & 44 & English & Design Studio & 12 \\
\hline 16 & $\begin{array}{l}\text { Marmara } \\
\text { University }\end{array}$ & Faculty of Fine Arts & Interior Architecture & $\begin{array}{l}\text { Special } \\
\text { Ability }\end{array}$ & 24 & Turkish & $\begin{array}{c}\text { Interior } \\
\text { Architecture Design }\end{array}$ & 10 \\
\hline 17 & $\begin{array}{l}\text { Mimar Sinan } \\
\text { University Of Fine } \\
\text { Arts }\end{array}$ & Faculty of Architecture & Interior Architecture & $\begin{array}{l}\text { Special } \\
\text { Ability }\end{array}$ & 30 & Turkish & $\begin{array}{c}\text { Interior } \\
\text { Architecture Project }\end{array}$ & 8 \\
\hline 18 & $\begin{array}{l}\text { Nişantaş1 } \\
\text { University }\end{array}$ & Faculty of Art and Design & Interior Architecture & $\begin{array}{l}\text { Special } \\
\text { Ability }\end{array}$ & 60 & Turkish & Design Studio & 8 \\
\hline 19 & Okan University & Faculty of Fine Arts & Interior Architecture & $\begin{array}{l}\text { Special } \\
\text { Ability }\end{array}$ & 90 & Turkish & $\begin{array}{c}\text { Interior } \\
\text { Architecture and } \\
\text { Environmental } \\
\text { Design }\end{array}$ & 7 \\
\hline 20 & Toros University & Faculty of Fine Arts & Interior Architecture & $\begin{array}{l}\text { Special } \\
\text { Ability }\end{array}$ & 50 & Turkish & Design Studio & - \\
\hline 21 & $\begin{array}{l}\text { Yeditepe } \\
\text { University }\end{array}$ & Faculty of Fine Arts & Interior Architecture & $\begin{array}{l}\text { Special } \\
\text { Ability }\end{array}$ & 80 & Turkish & Proje & 8 \\
\hline 22 & $\begin{array}{l}\text { Yeniyüzy1l } \\
\text { University }\end{array}$ & $\begin{array}{l}\text { Faculty of Engineering and } \\
\text { Architecture }\end{array}$ & Interior Architecture & $\begin{array}{l}\text { Special } \\
\text { Ability }\end{array}$ & 50 & Turkish & $\begin{array}{c}\text { Interior } \\
\text { Architecture Project }\end{array}$ & 8 \\
\hline 23 & Zirve University & $\begin{array}{l}\text { Faculty of Architecture and } \\
\text { Design }\end{array}$ & Interior Architecture & $\begin{array}{l}\text { Special } \\
\text { Ability }\end{array}$ & 80 & Turkish & $\begin{array}{l}\text { Indoor Design } \\
\text { Studio }\end{array}$ & 8 \\
\hline 24 & $\begin{array}{l}\text { Eastern } \\
\text { Mediterranean } \\
\text { University (Kktc) }\end{array}$ & Faculty of Architecture & Interior Architecture & $\begin{array}{l}\text { Special } \\
\text { Ability }\end{array}$ & 62 & English & $\begin{array}{c}\text { Interior } \\
\text { Architecture Design }\end{array}$ & 8 \\
\hline 25 & $\begin{array}{l}\text { Eastern } \\
\text { Mediterranean } \\
\text { University (Kktc) }\end{array}$ & Faculty of Architecture & Interior Architecture & $\begin{array}{l}\text { Special } \\
\text { Ability }\end{array}$ & 82 & Turkish & $\begin{array}{l}\text { Interior } \\
\text { Architecture } \\
\text { Workshop }\end{array}$ & 8 \\
\hline 26 & $\begin{array}{l}\text { Girne American } \\
\text { University } \\
\text { (Turkish Republic } \\
\text { Of Northern } \\
\text { Cyprus) }\end{array}$ & $\begin{array}{l}\text { Faculty of Architecture, } \\
\text { Design and Fine Arts }\end{array}$ & Interior Architecture & $\begin{array}{l}\text { Special } \\
\text { Ability }\end{array}$ & 80 & Turkish & $\begin{array}{l}\text { Interior Design } \\
\text { Studio }\end{array}$ & 10 \\
\hline 27 & $\begin{array}{l}\text { European } \\
\text { University Of } \\
\text { Lefke (Turkish } \\
\text { Republic Of } \\
\text { Northern Cyprus) }\end{array}$ & $\begin{array}{l}\text { Faculty of Architecture and } \\
\text { Engineering }\end{array}$ & Interior Architecture & $\begin{array}{l}\text { Special } \\
\text { Ability }\end{array}$ & 75 & Turkish & Could not access inf & mation \\
\hline 28 & $\begin{array}{l}\text { Cyprus } \\
\text { International } \\
\text { University }\end{array}$ & Faculty of Fine Arts & Interior Architecture & $\begin{array}{l}\text { Special } \\
\text { Ability }\end{array}$ & 69 & Turkish & $\begin{array}{c}\text { Interior } \\
\text { Architecture Project }\end{array}$ & 8 \\
\hline 29 & $\begin{array}{l}\text { Near East } \\
\text { University }\end{array}$ & Faculty of Architecture & Interior Architecture & $\begin{array}{l}\text { Special } \\
\text { Ability }\end{array}$ & 150 & Turkish & $\begin{array}{c}\text { Interior } \\
\text { Architecture Studio }\end{array}$ & 8 \\
\hline
\end{tabular}




\section{Conclusion}

As one of today's popular professions, Interior Architecture is offered by more departments every day. This growth in number must be achieved in a controlled manner without hindering the educational life. Sufficient number of academicians at departments with more students and controlled number of students for each academic member contribute to the institutionalization of education. The concepts of time and space are important for design studios as the building stone of Interior Architecture education. Design education is a concept defined with different perspectives. The main reason for this is approaching design studios, an effective course at Interior Architecture departments, with different educational methods. The content of Interior Architecture education, educational institutions, student selection methods and education models must be developed; methods and education models must be developed; methods based on out-of-date ideas and perspectives must be re-analysed and formatted for the future to accomplish an appropriate profession [7]. Considering design studios as an environment for design-experience, methods supporting design and design process become more important. Design studio is an education system focusing on addressing the design problematic. Therefore, in order for design studios to take shape, the student must be empowered as an interior architect to instill responsibility and self-confidence in them. Hence the design process is the most important factor in design studios with the executor guiding the course. The students are expected to think in a sophisticated manner, to seek alternatives; to make analysessyntheses, and to make assessments as open-minded individuals who take criticism well. In this sense, favorable conditions must be ensured particularly for workshops supporting design process. Accordingly, the study makes the following suggestions: Ensure students gain experience under supervision of academicians, Distribute sufficient number of students to academic members in design studio courses, Increase education models focusing on design and practice, Create spaces facilitating a favorable ambiance for design courses, Increase design studio course hours and reduce number and hours of other applied courses within the department. And finally, the design studio must not be limited to the workshop, and supporting activities must be conducted, including relevant research, trips, on-site observation, field studies and other workshops. The purpose must be provide the sector with prospective Interior Architects who are competent, creative, and responsible with the ability of critical thinking. The design studio course hours must be increased, and it must be included in the curricula of especially senior students in the form of a full day professional practice. Accordingly, the study emphasizes that the design studio is the main focus of interior architecture education, highlighting it as a vital component of education.

\section{References}

1. Adıgüzel, D., Türkiye'deki iç mimarlık eğitiminde çevresel yaklaşım, Master's Thesis, Kadir Has University, Istanbul, page 42, (2011).

2. Bielefeld, B., Khouli, S.E., Adım Adım Tasarım Fikirleri, Yem Publishing, İstanbul, (2010).

3. Cordan, Ö., Görgül, E., Çinçik, B., Numan, B., İç Mimarlık Eğitiminde Günceli Yakalamak: İTÜ Örneği, İÇMEK/Interior Architecture Education 2nd National Congress, Istanbul, Turkey, Dec 20, 2012, p.13. [1]May, B. (2008). "Nancy Vincent McCelland: Professionalizing Interior Decoration in the Early Twentieth Century", 
Journal of Design History, (21): 1:59-74. [2]Massey, A. (2008). Interior Design Since 1900: Thames and Hudson Publications), (2012).

4. Demirbaş, O. Ö., Design Studio as a life space, Bilkent University, Institute of Sciences, Master's Thesis, Ankara. p.45, (1997).

5. Ertürk, Z., Manav B., İkü İç Mimarlık Örneği Üzerinden Eğitim Programı Analizi, İCMEK/Interior Architecture Education 2nd National Congress, Istanbul, Turkey, Dec 20, 2012, p.13. (Kaynak: IIDA International Interior Design Association, (www.iida.org/../what-is-interior-design), (2012).

6. İnceoğlu, N., Gürer T., \& Çil, E., Düşünme ve anlatım aracı olarak eskizler, Helikon Publishing, İstanbul, sayfa 7, (1995).

7. Kaptan, B., Türkiye'de İç mimarlık eğitimin geleceği ve mesleğin yeniden yapılanma sorunu, 1st National Interior Architecture Symposium Approaches For Future, MSGSU Architecture Faculty Publishing, No:1, October 2008, p.376, (2008).

8. Ketizmen, G.Ç., Mimari Tasarım Stüdyosunun Biçimlenmesinde Yöntemsel ve Mekansal Etkilerin İncelenmesi, Anadolu University, Institute of sciences, Master's Thesis, August 2002, p.3, 32, 34, 46, (2002).

9. Özker, S., In the context of interior architecture departments in Turkey: Education Models, German-Turkish Year of Science, Hacettepe University, presented at the 1st International Interior Architecture Education symposium. (To be published in the memo booklet) December 11, 2014, (2014).

10. Öztürk, Ö.B., Günümüz Tasarım Eğitiminde Yöntem-Üslup Çekişmesi ve Sonuçları Üzerine Bir Deneme, International Conference on New Trends in Education and Their Implications, 11-13 November, 2010 Antalya-Turkey, s.449, (2010).

11. Tuğlu Karslı U., Özker S., "Günümüz Tasarım Stüdyolarında Uygulanan Eğitim Yöntemleri ve Atölyenin Mekansal Kurgusuna Etkisi" Yap1 Dergisi, Monthly Architecture, Design, Culture and Art Magazine, 402, May 2015, 86-87, (2015).

12. Yıldırım S., Güvenç K., Mimarlık Eğitiminde Tasarım Atölyeleri, Mimarlık Eğitimi Forum 1: Nasıl Bir Gelecek? Memos, ITU, Istanbul, 182-186, (1995).

13. Zorlu, T., Akgül, B., Erbay, M., Onur, D., Aras, A., İç mimarlık eğitiminde ilk yıl tasarım stüdyolarına farklı bir bakış; resimden mekana kandinsky, İÇMEK/Interior Architecture Education 2nd National Congress, Istanbul, Turkey, Dec 20, 2012, p. 43, (2012).

14. URL 1., The council for interior design accreditation, October, 2011, retrieved from http://accredit-id.org/professional-standards, (2009). 